\title{
Biodegradation and phytotoxicity of crude oil hydrocarbons in an agricultural soil
}

\author{
Wasen Abdul-Ameer Ali ${ }^{*}$ \\ ${ }^{1}$ Southern Technical University, College of Health and Medical Technology, Department of Community Health Technology, Basra, \\ Iraq. "Corresponding author (wasen336@yahoo.com).
}

Received: 1 November 2018; Accepted: 30 January 2019; doi:10.4067/S0718-5839201900020266

\begin{abstract}
Land treatment of crude oil is used by the oil industry, since it has been recognized that hydrocarbons (HC) can be metabolized by the indigenous microbial community of soil. The crude oil biodegradation in agricultural soil was studied for 12-mo to determine the $\mathrm{HC}$ biodegradation and leaching, the effect of $\mathrm{HC}$ on barley productivity and soil properties, and the potential for $\mathrm{HC}$ uptake in the plant. Concentration and composition of $\mathrm{HC}$ in the soil were periodically determined at a depth of 0 to $75 \mathrm{~cm}$. The $\mathrm{HC}$ concentration decreased over time due mainly to the microbial degradation. At the end, $12 \%$ of the primary crude oil amount remained constant in the soil. A vertical migration, leaching and metabolic products of HC into subsoil occurred. The HC have changed soil fertility. Barley has been successfully cultivated in soil but the $\mathrm{HC}$ reduced some plant growth parameters. However, $\mathrm{HC}$ were not detected in plant seeds. Many of oil-utilizing bacteria and fungi were isolated from soil. The HC biodegradation potential of oil polluted soil (6\% to 66\%) were higher than of unpolluted one ( $4 \%$ to $53 \%$ ). The bacteria ( $22 \%$ to $66 \%$ ) were more active than fungi ( $4 \%$ to $46 \%$ ) in HC biodegradation. The study demonstrated that agricultural lands with low rates of oil contamination allows the growth of plants. They ensure high efficiency of HC biodegradation. Vertical infiltration plays an important role in HC removing from soil. Alkanes were completely assimilated by microorganisms and polar compounds were more resistant to microbial attack.
\end{abstract}

Key words: Agricultural soil, bacteria, biodegradation, crude oil, fungi.

\section{INTRODUCTION}

Environmental pollution due to accidental oil spillage, leakage and disruption of oil pipelines is very common and has become a major concern for governments, ecologists and communities (Ikuesan, 2017). The release of oil into the environment is causing considerable damage to the ecosystem (Han et al., 2016). The toxicity of petroleum hydrocarbons (HC) to organisms is well established (Eze et al., 2014).

Soil pollution with oil is the major global concern today. It may lead to delayed plant growth, soil infertility, and changes in soil physicochemical and microbiological properties (Ikuesan, 2017). It might cause organically contaminated groundwater and poses a significant risk to human health (Chukwura et al., 2016). The oil impacts may lead to lower agricultural productivity and thus adversely affect the socioeconomic of people life (Chorom et al., 2010). The negative impact of oil contamination has necessitated the exploration of many strategies to return contaminated sites to a nonpolluted state. The physical and chemical techniques for oil treatment currently used are expensive and not environmentally friendly (Jain et al., 2011). Recently, much effort has been made to treat the oil pollution using natural processes that include bioremediation and phytoremediation (Jahangeer and Kumar, 2013).

Bioremediation is a natural process in which microorganisms transform environmental pollutants into harmless final products to obtain $\mathrm{C}$ and energy sources. It is simple way and easy to maintain, applicable to large areas, cost-effective, and conducive to complete destruction of pollutants (Omotayo et al., 2012). Many factors such as nutrients, temperature, oxygen, etc., affect biodegradation of HC (Jahangeer and Kumar, 2013). Basically, there are two different approaches to 
bioremediation techniques. The first involves the activation of indigenous microorganisms in the contaminated area by adding nutrients and forming the best environmental conditions (biostimulation). The second is bioaugmentation, which involves adding oil-utilizing or genetically modified microorganisms (Ikuesan, 2017).

A variety of microbes with the ability to metabolize HC can be easily isolated from soil (Eze et al., 2014). The soil with high HC content contains more HC-utilizers than soil with low HC content (Olajire and Essien, 2014). While most $\mathrm{HC}$ biodegradation studies focus on bacteria, fewer investigations deal with fungi. Biodegradation of $\mathrm{HC}$ in marine environments has been well studied. However, there are lesser studies in soil ecosystems in general and in agricultural soils in particular. Therefore, the objective of this study was to determine the potential $\mathrm{HC}$ degradation of bacteria and fungi isolated from contaminated and non-polluting agricultural soils. In addition, $\mathrm{HC}$ leaching into the soil was determined and the effects of crude oil on the barley and soil properties were considered. The uptake of HC by plant was also evaluated.

\section{MATERIAL AND METHODS}

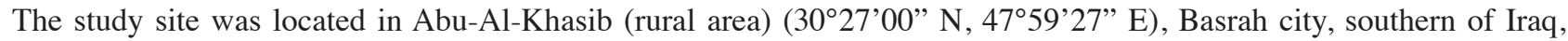
where the HC contamination is possible from oil spill accidents and oil wastes discharged from various agricultural machines and residents in the region. A tow experimental fields $\left(200 \mathrm{~m}^{2}\right)$ were designed in an agricultural soil during November 2016 to October 2017. The soil characteristics are shown in (Table 1). One of the fields (F1) was spread with $12 \mathrm{~g} \mathrm{~m}^{-2}$ of Nahran-Omer crude oil with an agricultural spreader. The gas chromatographic analysis of the initial crude oil composition is demonstrated in Figure 1. The crude oil composed of 50\% aliphatic HC, 40\% aromatics, and 10\% polar compounds. The other field (F2) was left unpolluted (control). A drainage system was designed and buried at a distance

Table 1. Characteristics of the agricultural soil at 0 to $75 \mathrm{~cm}$ depth.

\begin{tabular}{lccccc}
\hline & $0-15 \mathrm{~cm}$ & $15-30 \mathrm{~cm}$ & $30-45 \mathrm{~cm}$ & $45-60 \mathrm{~cm}$ & $60-75 \mathrm{~cm}$ \\
\hline $\mathrm{pH}$ & 7.8 & 7.7 & 7.6 & 7.6 & 7.5 \\
$\mathrm{Silt}, \%$ & 31.3 & 33.7 & 34.2 & 36.1 & 35.0 \\
Clay, \% & 71.5 & 73.4 & 68.7 & 68.2 & 67.2 \\
Sand, \% & 4.5 & 3.2 & 4.0 & 3.3 & 4.1 \\
Texture & Clay & Clay & Clay & Clay & Clay \\
Total Ca, \% & 0.4 & 0.4 & 0.2 & 0.3 & 0.2 \\
$\mathrm{P}_{2} \mathrm{O}_{2}, \%$ & 0.1 & 0.07 & - & - & - \\
Total N, \% & 0.1 & 0.07 & 0.06 & 0.04 & 0.03 \\
Organic matter, \% & 2.6 & 1.8 & 1.0 & 0.4 & 0.1 \\
C/N & 7.7 & 7.4 & 7.6 & 7.3 & 7.1 \\
\hline
\end{tabular}

Figure 1. Chromatograms of crude oil hydrocarbons analysis.

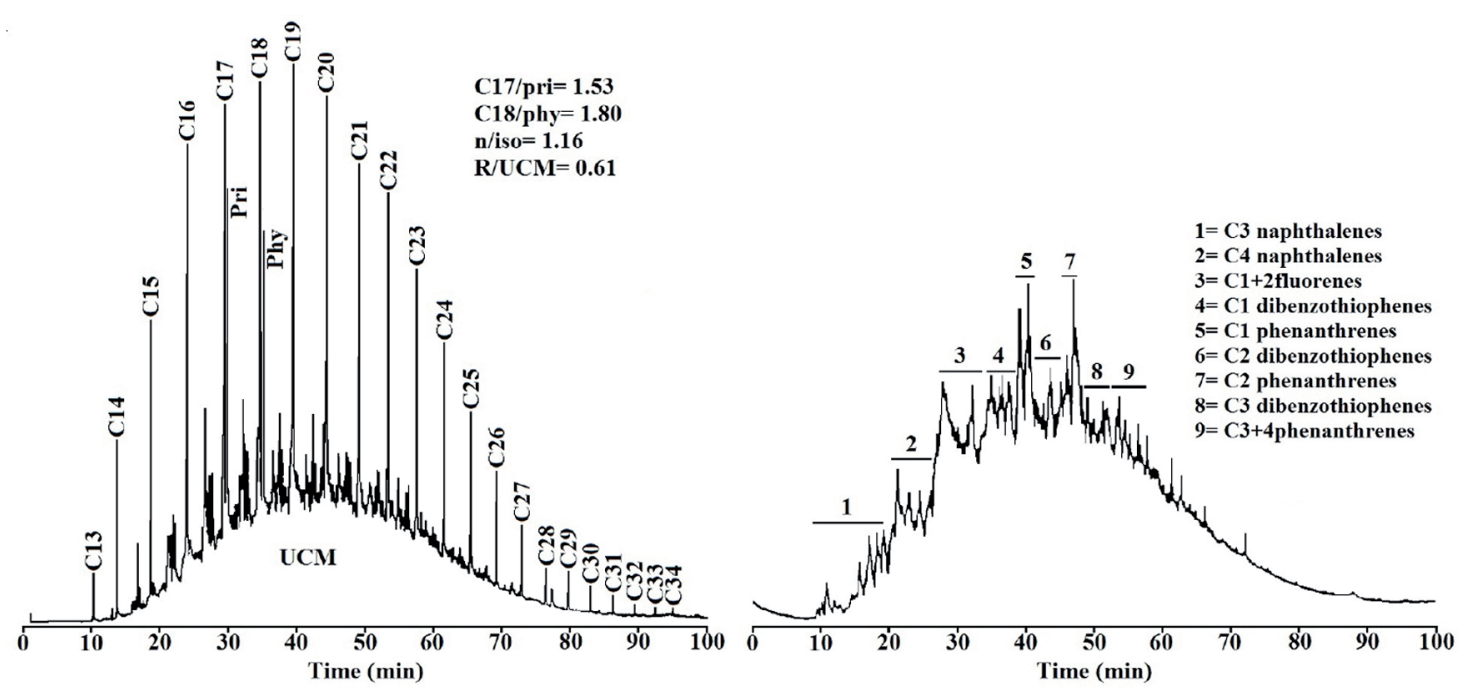

Pri: Pristane; Phy: Phytane; n/iso: n-alkanes/iso-alkanes; R/UCM: resolved n-alkanes/unresolved complex mixture; UCM: unresolved complex mixture. 
of $50 \mathrm{~cm}$ below the soil surface, allowing leachate collection from F1 and F2. Both fields were immediately tilled after oil treatment and barley (Hordeum vulgare L.) cultivation. Sowing was performed $2 \mathrm{~d}$ after crude oil spreading during November 2016. Five days later, fields were fertilized with $2.8 \mathrm{~kg} \mathrm{~N}, 2.8 \mathrm{~kg} \mathrm{P}_{2} \mathrm{O}_{2}$ and $2.8 \mathrm{~kg} \mathrm{~K}_{2} \mathrm{O}$, applied to $200 \mathrm{~m}^{2}$. Soil samples were collected from both fields at different periods (7, 14, and $21 \mathrm{~d}$ and 1, 2, 4, 6, 8, 10, and 12-mo) and depths $(0$ to $75 \mathrm{~cm})$. The samples were homogenously mixed and carefully sorted to remove unwanted soil debris. Barley was harvested in April 2017. Plant density, height, and grain yield were measured in the two fields. Seed samples were collected from the plant when harvested. Drainage water samples were periodically collected from drainage system during rain periods.

Soil samples $(50 \mathrm{~g})$ and seeds were dried $\left(60^{\circ} \mathrm{C}\right.$ for $\left.12 \mathrm{~h}\right)$ and Soxhlet-extracted for $8 \mathrm{~h}$ with $250 \mathrm{~mL}$ chloroform. The $\mathrm{HC}$ were extracted from water with $50 \mathrm{~mL}$ chloroform $\mathrm{L}^{-1}$ water, three times in separator funnel for $30 \mathrm{~min}$. The extract was reduced in volume by a rotary evaporator, dried by $\mathrm{Na}_{2} \mathrm{SO}_{4}$, and concentrated by pure $\mathrm{N}$. The extract was then purified by percolating on florisil column (60 to 100 mesh), evaporated in a pre-weighed dish and weighed. It was then fractionated to aliphatic, aromatic, and polar fractions by successive elution with n-hexane, benzene, and methanol, respectively, on chromatography column. The column was prepared by slurry packing $10 \mathrm{~g}$ silica, followed by $10 \mathrm{~g}$ alumina and finally $1 \mathrm{~g}$ $\mathrm{Na}_{2} \mathrm{SO}_{4}$ was added to the surface. The fractions were concentrated and transferred to a vial. A sample $(1 \mu \mathrm{L})$ of aliphatic or polar fraction was analyzed by capillary gas chromatography (GC; Agilent, Santa Clara, California, USA). Helium gas was used as the carrier gas with flow rate of $1.5 \mathrm{~mL} \mathrm{~min}^{-1}$. The operating temperatures for detector and injector were $350^{\circ} \mathrm{C}$. The silica capillary column was operated under temperature programming, 100 to $320^{\circ} \mathrm{C}, 3{ }^{\circ} \mathrm{C} \mathrm{min}^{-1}$. The aromatic fraction $(1 \mu \mathrm{L})$ was identified by gas chromatography-mass spectrometry (GC-MS; QP-1000A, Shimadzu, Kyoto, Japan) interfaced with mass-selective detector (MSD) using the same chromatographic conditions. Individual HC were identified based on the retention time and $\mathrm{m} / \mathrm{z}$ ratio of the $\mathrm{HC}$ authentic standards. The $\mathrm{HC}$ concentrations were calculated based on the standard calibration curve of each corresponding standard compound. For quality assurance and quality control, method blanks were analyzed. None of the target compounds was detected. The recovery and relative standard deviation for aliphatic HC were in the range of $83 \%$ to $92 \%$ and $3.9 \%$ to $18.6 \%$ respectively. The detection limits of the method range from 4.2 to $13.3 \mu \mathrm{g} \mathrm{g}^{-1}$. For aromatics, the average recoveries of standards varied from $83.5 \%$ to $91 \%$ and the detection limit ranged from 0.2 to $0.8 \mathrm{ng} \mathrm{g}^{-1}$.

Enumeration and isolation of heterotrophic bacteria (HB) and fungi (HF) and oil-utilizing bacteria (OUB) and fungi (OUF) from soil samples were performed by dilution plate method. Nutrient agar (NG) medium, Sabouraud dextrose agar (SDA) medium and mineral medium (MM) were used to enumerate and isolate the HB, HF and OUB and OUF respectively. A 7-fold serial dilutions were made using $1 \mathrm{~g}$ soil and $1 \mathrm{~mL}$ from appropriate dilutions were plated in duplicate on culture media by pour plate method. The plates were swirled, allowed to solidify and incubated at $28 \pm 2{ }^{\circ} \mathrm{C}$ for $7 \mathrm{~d}$ for $\mathrm{HF}$ and $21 \mathrm{~d}$ for OUF and at $37^{\circ} \mathrm{C}$ for $24 \mathrm{~h}$ for $\mathrm{HB}$ and $21 \mathrm{~d}$ for OUB. The MM contained $0.1 \mathrm{~mL}$ sterile crude oil into a filter paper lining every Petri-dish cover. It was composed of $1 \mathrm{~g} \mathrm{NaNO}_{3} \mathrm{~L}^{-1}, 0.6 \mathrm{~g} \mathrm{KH}_{2} \mathrm{PO}_{4} \mathrm{~L}^{-1}, 0.9 \mathrm{~g} \mathrm{Na}_{2} \mathrm{HPO}_{4} \mathrm{~L}^{-1}, 0.2 \mathrm{~g}$ $\mathrm{K}_{2} \mathrm{SO}_{4} \mathrm{~L}^{-1}, 0.4 \mathrm{~g} \mathrm{MgSO}_{4} \cdot 7 \mathrm{H}_{2} \mathrm{O} \mathrm{L}^{-1}, 0.7 \mathrm{~g} \mathrm{CaCl}_{2} \cdot 2 \mathrm{H}_{2} \mathrm{O} \mathrm{L}{ }^{-1}, 2.5 \mathrm{~mL}$ trace element mixture $\left(2.3 \mathrm{~g} \mathrm{ZnSO}_{4} \mathrm{~L}^{-1}, 1.8 \mathrm{~g} \mathrm{MnSO}_{4} \mathrm{~L}^{-1}\right.$, $0.6 \mathrm{~g} \mathrm{H}_{3} \mathrm{BO}_{3} \mathrm{~L}^{-1}, 1 \mathrm{~g} \mathrm{CuSO}_{4} \mathrm{~L}^{-1}, 0.4 \mathrm{~g} \mathrm{Na}_{2} \mathrm{MoO}_{4} \mathrm{~L}^{-1}, 0.4 \mathrm{~g} \mathrm{CoCl}_{2} \mathrm{~L}^{-1}, 0.7 \mathrm{~g} \mathrm{KI} \mathrm{L}^{-1}, 1 \mathrm{~g}$ EDTA L ${ }^{-1}, 0.4 \mathrm{~g} \mathrm{FeSO}_{4} \mathrm{~L}^{-1}$, and $0.004 \mathrm{~g}$ $\left.\mathrm{NiCl}_{2} \mathrm{~L}^{-1}\right)$ and $20 \mathrm{~g} \mathrm{~L}^{-1}$ agar. Chloramphenicol was added $\left(500 \mathrm{mg} \mathrm{L}^{-1}\right)$ to the fungi $\mathrm{MM}$ for bacterial growth inhibition.

The bacterial and fungal colonies were enumerated and recorded as colony forming units (CFU) $1 \mathrm{~g}^{-1}$ soil sample. Pure cultures were obtained by repeated sub culturing on fresh NG and SDA media. The pure cultures were maintained on agar slants. Each picked individual colony of bacteria and fungi was cultured on liquid $\mathrm{MM}(50 \mathrm{~mL})$ in $250 \mathrm{~mL}$ Erlenmeyer flasks to which $0.1 \mathrm{~mL}$ of crude oil was added. After $21 \mathrm{~d}$ of incubation in an orbital shaker set at $150 \mathrm{rpm}$ in $37{ }^{\circ} \mathrm{C}$ (bacteria) and $28 \pm 2{ }^{\circ} \mathrm{C}$ (fungi), the strains that showed a visible growth were scored as potentially able to use crude oil. Fungi were identified according to general principles of fungal classification (Gadd et al., 2007). A primary bacterial identification was performed according to their morphological characteristics and biochemical tests (Holt et al., 1994). The bacterial strains molecular identification were done based on 16S rRNA, the DNA extraction kit (Sigma, USA) was used to extract bacterial DNA. The 1500 bp $16 \mathrm{~S}$ rRNA fragment was amplified by polymerase chain reaction (PCR) using the universal primers (FD1 and RP1). The amplification products were subjected to electrophoresis on agarose gel followed by ethidium bromide staining. The primers were removed and the purified PCR products were sequenced (Macrogen, Seoul, Korea). The obtained sequences were identified by compared them with those of GenBank database using the Blast server at National Center for Biotechnology Information (NCBI, Bethesda, Maryland, USA). 
The microbial strains were separately tested for their biodegradation potential in 250 Erlenmeyer flasks containing 150 $\mathrm{mL} \mathrm{MM}$ and $180 \mathrm{mg}$ crude oil. Control flasks were left without microbes and containing $500 \mathrm{mg} \mathrm{HgCl}_{2} \mathrm{~L}^{-1}$ to quantify the abiotic losses by evaporation. The flasks were incubated at $37{ }^{\circ} \mathrm{C}$ (bacteria) and $28 \pm 2{ }^{\circ} \mathrm{C}$ (fungi) in an orbital shaker set at $150 \mathrm{rpm}$ for $30 \mathrm{~d}$. The residual $\mathrm{HC}$ were then extracted from culture medium with $50 \mathrm{~mL}$ chloroform and filtered through sterile $0.45 \mu \mathrm{m}$ Millipore filter. The extract was reduced in volume to measure the residual oil by spectrofluorometer (RF540; Shimadzu, Kyoto, Japan) equipped with a DR-3-data recorder. The HC were quantified by measuring the emission intensity at $360 \mathrm{~nm}$, with excitation set at $310 \mathrm{~nm}$ and monochromatic slits of $10 \mathrm{~nm}$. The percentage biodegradation of each strain was then determined by the equation:

$$
(I-R) \times R \times 100 / I
$$

where $I$ and $R$ are the initial and residual HC contents respectively. Thereafter, the extract was separated to aliphatic, aromatic and polar fractions and analyzed by GC and GC-MS using the same previous chromatographic conditions. The percentage biodegradation of each fraction was determined as Equation [1].

Total organic C (TOC) was measured in water samples by wet oxidation method of Walkey and Black. Data statistical analysis was performed by ANOVA, with differences determined by the least significant differences method at the 5\% level $(\mathrm{P}<0.05)$. Statistical analysis were run with SPSS 16.0 version for Windows program (IBM, Armonk, New York, USA).

\section{RESULTS AND DISCUSSION}

The GC analysis reflected that the F2 soil was composed mainly of biogenic n-alkanes (C25 to C33) with Carbon Preference Index (CPI) value of 8 . Most of these HC ( 1 to $2 \mathrm{mg} \mathrm{kg}^{-1}$ ) were detected at 0 to $30 \mathrm{~cm}$ soil depth, while less amount of them $\left(0.2\right.$ to $\left.1 \mathrm{mg} \mathrm{kg}^{-1}\right)$ were existed in 30 to $75 \mathrm{~cm}$ depth. The study showed that the crude oil in F1 can be biodegraded by agricultural soil microbial community. After $7 \mathrm{~d}$, HC concentration in soil decreased to $37.5 \mathrm{mg} \mathrm{kg}^{-1}$ at 0 to $15 \mathrm{~cm}$ depth and $21.1 \mathrm{mg} \mathrm{kg}^{-1}$ at 60 to $75 \mathrm{~cm}$ depth.

Initially, the GC analysis revealed that only the C14 to C20 n-alkanes were presented in 30 to $75 \mathrm{~cm}$ soil depth. This selective migration of lightest HC may due to the chromatographic characteristics of the clays (Gawdzik and Zygadlo, 2010). Thereafter, the $n$-alkanes in the range of $\mathrm{C} 14$ to $\mathrm{C} 30$ were detected in all soil depths, indicating that the subsequent vertical migration of $\mathrm{HC}$ gradually involved all crude oil. Such selective vertical infiltration of $\mathrm{HC}$ has also been shown previously in contaminated soils (Essaid et al., 2011). After 2-mo of experiment, most of the crude oil (10 to $18 \mathrm{mg} \mathrm{kg}^{-1}$ ) was located at 0 to $30 \mathrm{~cm}$ soil depth. The crude oil concentration in this depth decreased continuously over time to 1.5 to $6 \mathrm{mg} \mathrm{kg}^{-1}$ after 12-mo (Figure 2).

The n-alkanes disappeared completely between 8 to 12-mo. The C17/pristane, C18/phytane, and (R)/unresolved complex matters Resolved n-alkanes/unresolved complex mixture (R/UCM) ratios decreased. The isoprenoids, pristane

Figure 2. Crude oil concentration at 0-15, 15-30, 30-45, 45-60 and 60-75 cm depths in soil of oil treated field (F1).

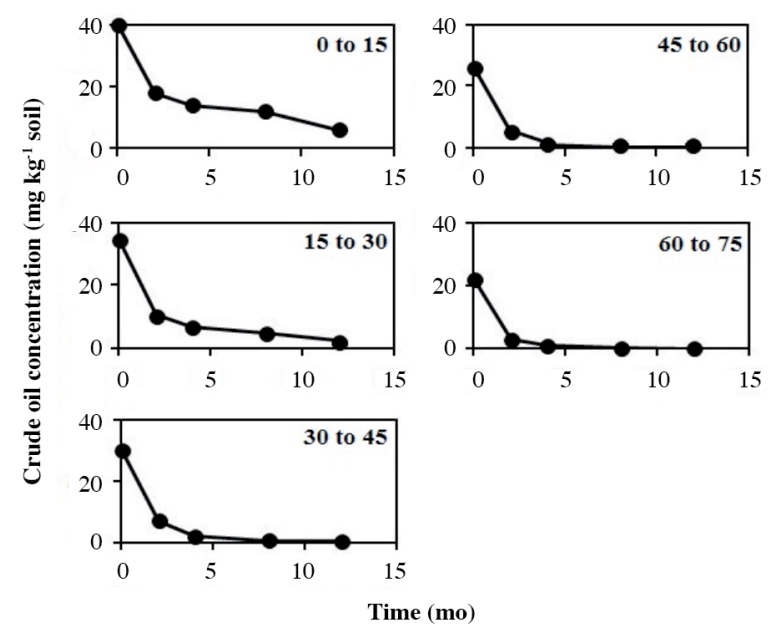


(pri) and phytane (phy) and GC resolved aromatic were resistant even after 12-mo with a significant decline in their concentrations were detected. It was reported that the low molecular weight $\mathrm{HC}$ tend to be degraded first, leaving behind the much larger molecules which take much longer to break down (Das and Chandran, 2011). The biogenic HC (C25 to C33) and crude oil HC traces did not degraded, although it was found that such $\mathrm{HC}$ were completely biodegraded by laboratory studies (Jahangeer and Kumar, 2013). This may be due to the fact that these HC in soil are associated with organic and mineral matter in such a way that they are protected from microorganisms consumption (Jahangeer and Kumar, 2013) (Table 2 and Figure 3).

The total residual of UCM consisted of $8 \% \mathrm{HC}$. These were relatively the same HC amount existing in UCM of initial crude oil, indicating the high UCM resistance for degradation. The UCM fundamentally consisted of polycyclic alkylated saturated and aromatic HC and T-shaped molecules. These components are known for their resistance to biodegradation and by their harmful environmental effects, especially the carcinogenic polycyclic aromatic HC (PAHs) (Guo et al., 2014).

Table 2. Hydrocarbons ratios indicating biodegradation of crude oil at 0 to $15 \mathrm{~cm}$ soil depth.

\begin{tabular}{lccc}
\hline Time & C17/Pri & C18/Phy & R/UCM \\
\hline $7 \mathrm{~d}$ & 0.75 & 0.84 & 0.18 \\
$2 \mathrm{mo}$ & 0.63 & 0.65 & 0.11 \\
$6 \mathrm{mo}$ & 0.50 & 0.51 & 0.07
\end{tabular}

Pri: Pristane; Phy: phytane; R/UCM: resolved n-alkanes/unresolved complex mixture.

Figure 3. Chromatograms showing biodegradation of crude oil hydrocarbons in soil of oil treated field (F1) at 0 to $15 \mathrm{~cm}$ depth over time.
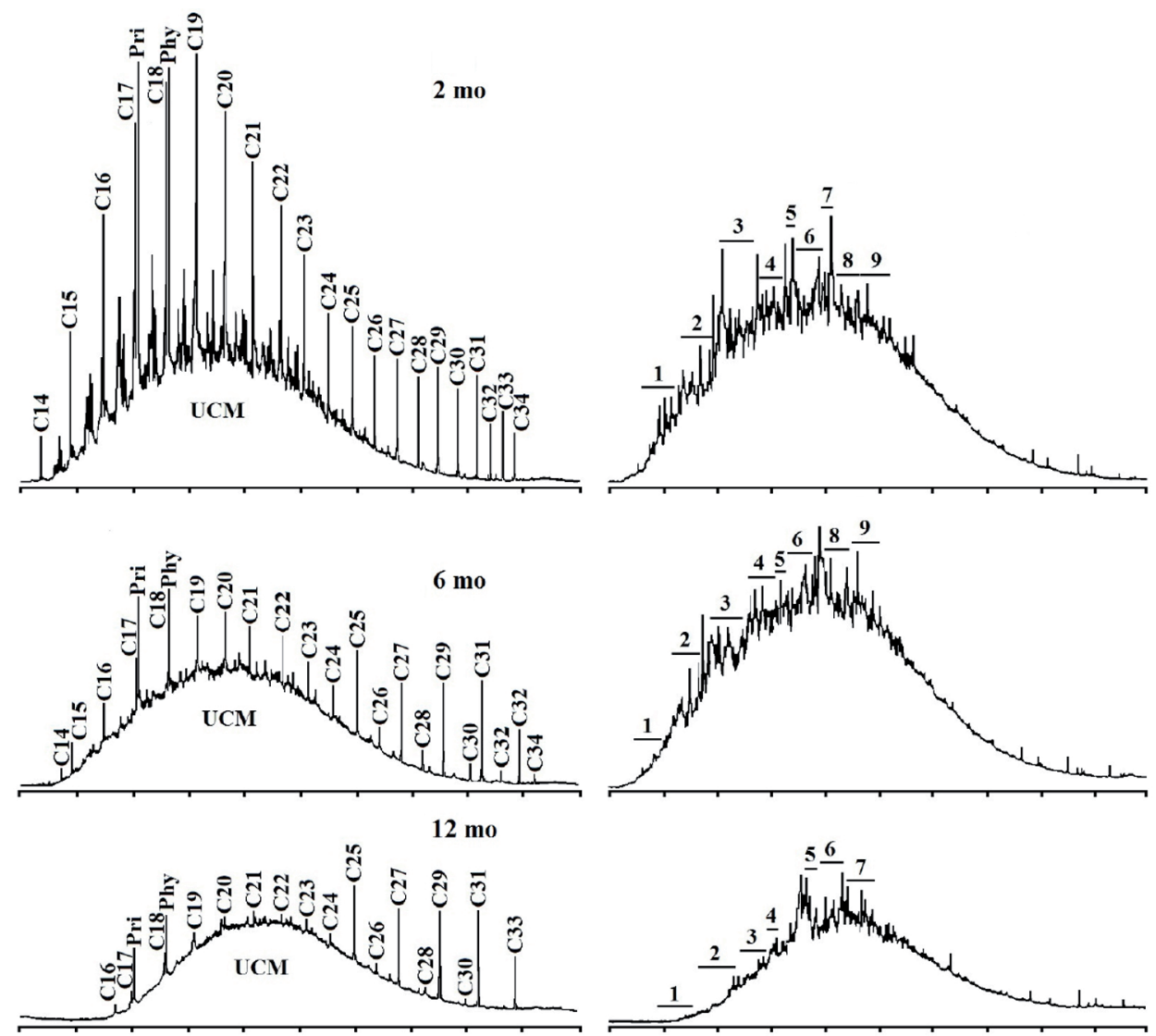

Pri: Pristane; Phy: phytane; UCM: unresolved complex mixture. 
The total HC concentration of all soil depths were calculated and plotted against time (12-mo) (Figure 4). The HC loss rate (biodegradation) for the whole experiment was $5.4 \mathrm{~g} \mathrm{~m}^{-2} \mathrm{mo}^{-1}$. This rate was high at the beginning of the experiment (first 6-mo) (7.9 $\left.\mathrm{g} \mathrm{m}^{-2} \mathrm{mo}^{-1}\right)$ compared to its end (remaining months) $\left(3 \mathrm{~g} \mathrm{~m}^{-2} \mathrm{mo}^{-1}\right)$. The total $\mathrm{HC}$ loss was up to $88 \%$ after 12-mo. In general, the biodegradation rate of this study was relatively similar to that reported by Dadrasnia and Agamuthu (2013). However, the previous laboratory studies (Makadia et al., 2011; Omotayo et al., 2012) have indicated that the biodegradation removed about $>80 \%$ of petroleum HC. This is suggested other abiotic factors involved in removing HC in the current study as well as the biodegradation process. It has been found that $\mathrm{HC}$ vertical flow into the soil may be one of the most abiotic mechanisms that contribute to the HC loss from soil surface (Gawdzik and Zygadlo, 2010).

The results showed that the $\mathrm{HC}$ concentration within the soil column ( 0 to $75 \mathrm{~cm}$ depth) ranged from $0.12 \mu \mathrm{g} \mathrm{g}^{-1} \mathrm{~d}^{-1}$ after a few days of experimental onset to less than $0.02 \mu \mathrm{g} \mathrm{g}^{-1} \mathrm{~d}^{-1}$ after 12-mo. This means that approximately $9 \%$ of the initial loading of $\mathrm{HC}$ has migrated to soil depth of $75 \mathrm{~cm}$ or more throughout the 12-mo. This occurs in accidental oil spills and in the agricultural soils where a large amounts of surface HC migrate deep into the soil. The HC that penetrate the soil column can biodegrade slowly because of the anaerobic conditions (Essaid et al., 2011).

The GC analysis revealed the presence of $\mathrm{HC}$ in the drainage water of F1. These compounds were due to the metabolic products leaching from petroleum biodegradation. The compounds may consist of organic acids and aromatic ketones (Das and Chandran, 2011). The study indicated that there is no significant difference in drainage water TOC of F1 and F2 during the first month of the experiment. In December 2016 and January 2017 the TOC was 3 times higher in F1 ( 7 to $8 \mathrm{mg} \mathrm{L}^{-1}$ ) than in F2 (4 to $5 \mathrm{mg} \mathrm{L}^{-1}$ ) (Figure 5). The HC concentration in drainage water of F1 was about $0.02 \mathrm{mg} \mathrm{L}^{-1}$.

The amount of excess soluble organic $\mathrm{C}$ was calculated on the whole experiment and was found to be in the range of $0.14 \mathrm{~g} \mathrm{~m}^{-2}$. The HC leaching considered abiotic way to crude oil loss from soil surface (Abatenh et al., 2017). The present study has detected the presence of numbers of microorganisms in drainage water. These microbes may play an important role in the HC degradation in drainage water and subsoil.

Figure 4. Crude oil concentration in soil of oil treated field (F1) against the time at 0-75 $\mathrm{cm}$ depth.

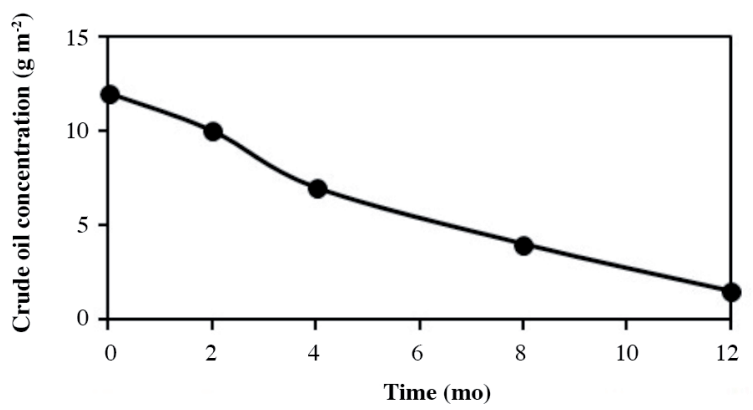

Figure 5. Temperature, rainfall and total organic C (TOC) in drainage water during the time of experiment.
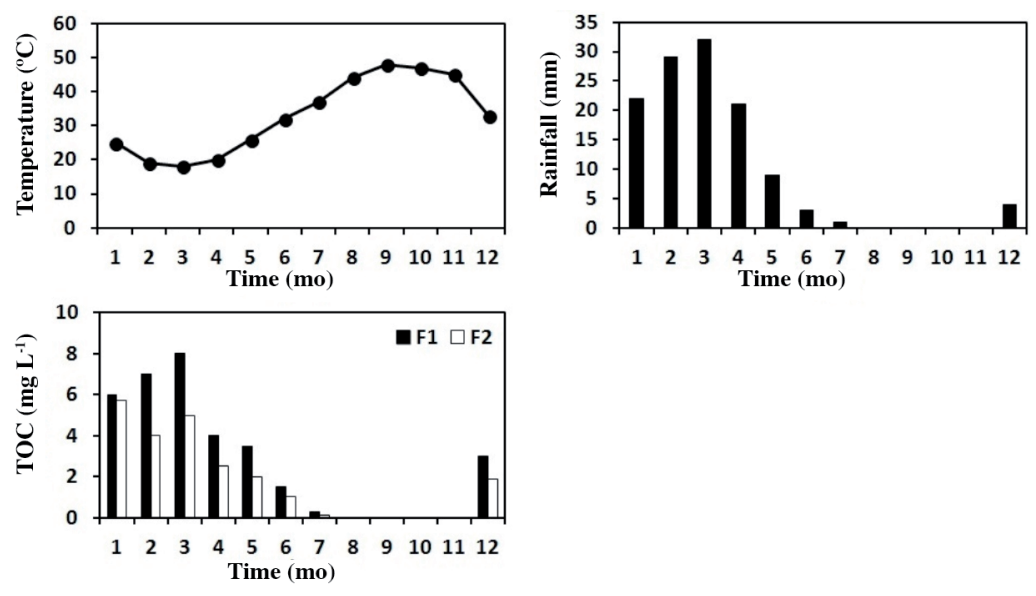
No effects of HC on seedling and density of barley were observed. Li et al. (2013) and Han et al. (2016) found that the germination responses of a number of plants to $\mathrm{HC}$ varied greatly depending on the type of plant. A considerable effects of crude oil on the barley physiology were detected. These included a reduction in the leaves number, acquisition of leaves a reddish color, delayed flowering, height reduction, and a significant decrease in grain yield (Table 3). This may be due to phytotoxic effects of petroleum HC (Li et al., 2013). The similar effects were reported by Fowzia Fakhruddin (2018) on the growth of maize in crude oil contaminated soil. However, the petroleum HC in barley seeds were not detected. The GC analysis only revealed a biogenic HC (C20 to C30) in seeds.

The crude oil caused a change in characteristics of $\mathrm{F} 1$ soil ( 0 to $15 \mathrm{~cm}$ depth) included an increase in the TOC and $\mathrm{pH}$ and decrease in available $\mathrm{P}$ and exchangeable $\mathrm{K}$. However, these modified in chemical fertility of soil did not affect the biodegradation process and plant growth. The Ca content and total and mineral $\mathrm{N}$ were not affected by crude oil (Table 4). The amount of mineral $\mathrm{N}$ added as fertilizer for plant cultivation was appropriate for biodegradation and plant growth. The $\mathrm{P}$ and $\mathrm{K}$ were also in sufficient amounts to stimulate the microbial degradation and plant growth. The temperature was typical for biodegradation. The temperature is one of the most important factors affecting the microbial HC degradation (Jahangeer and Kumar, 2013). Such effects of crude oil on soil parameters had also been reported by Hajabbasi (2016).

After 8-mo, the current study showed that there was almost an increase of 1000-fold and 10-fold for the OUB and HB, respectively, and by about 100 -fold and 50-fold for the OUF and HF, respectively in 0 to $15 \mathrm{~cm}$ soil depth of F1, compared to F2 (Figure 6). Where more than $88 \%$ of bacteria and fungi were adapted to crude oil utilization. The bacteria and fungi were found in the 15 to $75 \mathrm{~cm}$ soil depth (Table 5). It had usually been found that the numbers of aerobic microorganisms decreased with the soil depth (Jahangeer and Kumar, 2013). Tillage and drainage system enhanced soil ventilation and allowed microbial growth in the entire soil. The numbers of OUB and OUF were higher in the 0 to $45 \mathrm{~cm}$ soil depth where the concentration of $\mathrm{HC}$ was at maximum and in the 45 to $75 \mathrm{~cm}$ depth due to selective migration of light HC into soil (Essaid et al., 2011).

In F2, tilling and soil fertilization did not caused a significant change in the numbers of bacteria and fungi at 0 to 15 $\mathrm{cm}$ soil depth. The ratios of OUB/HB and OUF/HF remained perfectly stable, about $1 \%$. When the experiment is over, the microorganisms levels in F1 become similar to F2 (Figure 6).

Numerous genera of OUB and OUF were isolated and identified from F1 and F2 soils (Tables 6 and 7). Most of these genera had already been found in the oil contaminated sites elsewhere and identified as oil degraders (Dadrasnia and Agamuthu, 2013; Adams et al., 2015). However, some species such as Acremonium fusidioides, and Cunninghamella echinulata are not cited as oil degraders by other authors. The percentage biodegradation results of bacterial and fungal strains showed that these strains were able to degrade the petroleum HC at different rates (Tables 6 and 7). The HC assimilation between $32 \%$ and $66 \%$ and $30 \%$ and $46 \%$ were detected by active strains of OUB and OUF, respectively.

Table 3. Toxic effect of crude oil hydrocarbons on mature barley.

\begin{tabular}{lrr}
\hline Character & F2 & F1 \\
\hline Plant density, plant m ${ }^{-2}$ & 302 & 290 \\
Plant height, cm & 85 & 76 \\
Plant yield, g 200 m & -2 & 121 \\
\hline
\end{tabular}

F1: Oil treated field; F2: untreated field (control).

Table 4. Characteristics of soil at 0 to $15 \mathrm{~cm}$ depth.

\begin{tabular}{|c|c|c|c|c|c|c|}
\hline \multirow[b]{2}{*}{ Soil property } & \multicolumn{3}{|c|}{$\mathrm{F} 2$} & \multicolumn{3}{|c|}{$\mathrm{F} 1$} \\
\hline & $7 \mathrm{~d}$ & $4 \mathrm{mo}$ & $12 \mathrm{mo}$ & $7 \mathrm{~d}$ & $4 \mathrm{mo}$ & $12 \mathrm{mo}$ \\
\hline TOC, $\%$ & 7.1 & 8.3 & 8.9 & 9.5 & 9.7 & 9.9 \\
\hline Total Ca, \% & 0.40 & 0.39 & 0.42 & 0.38 & 0.37 & 0.29 \\
\hline $\mathrm{pH}$ & 7.1 & 6.9 & 6.7 & 7.1 & 7.3 & 7.5 \\
\hline $\mathrm{P}_{2} \mathrm{O}_{2}, \%$ & 0.14 & 0.12 & 0.11 & 0.07 & 0.08 & 0.09 \\
\hline $\mathrm{K}_{2} \mathrm{O}, \%$ & 0.20 & 0.14 & 0.10 & 0.18 & 0.10 & 0.09 \\
\hline Total N, \% & 1.0 & 1.0 & 0.9 & 1.2 & 1.1 & 0.9 \\
\hline Mineral N, \% & 0.05 & 0.06 & 0.07 & 0.04 & 0.07 & 0.06 \\
\hline
\end{tabular}

F1: Oil treated field; F2: untreated field (control); TOC: total organic C. 
Figure 6. Changes in bacterial and fungal numbers at 0-15 cm depth in soils of oil treated field (F1) and untreated field (control) (F2) over time.
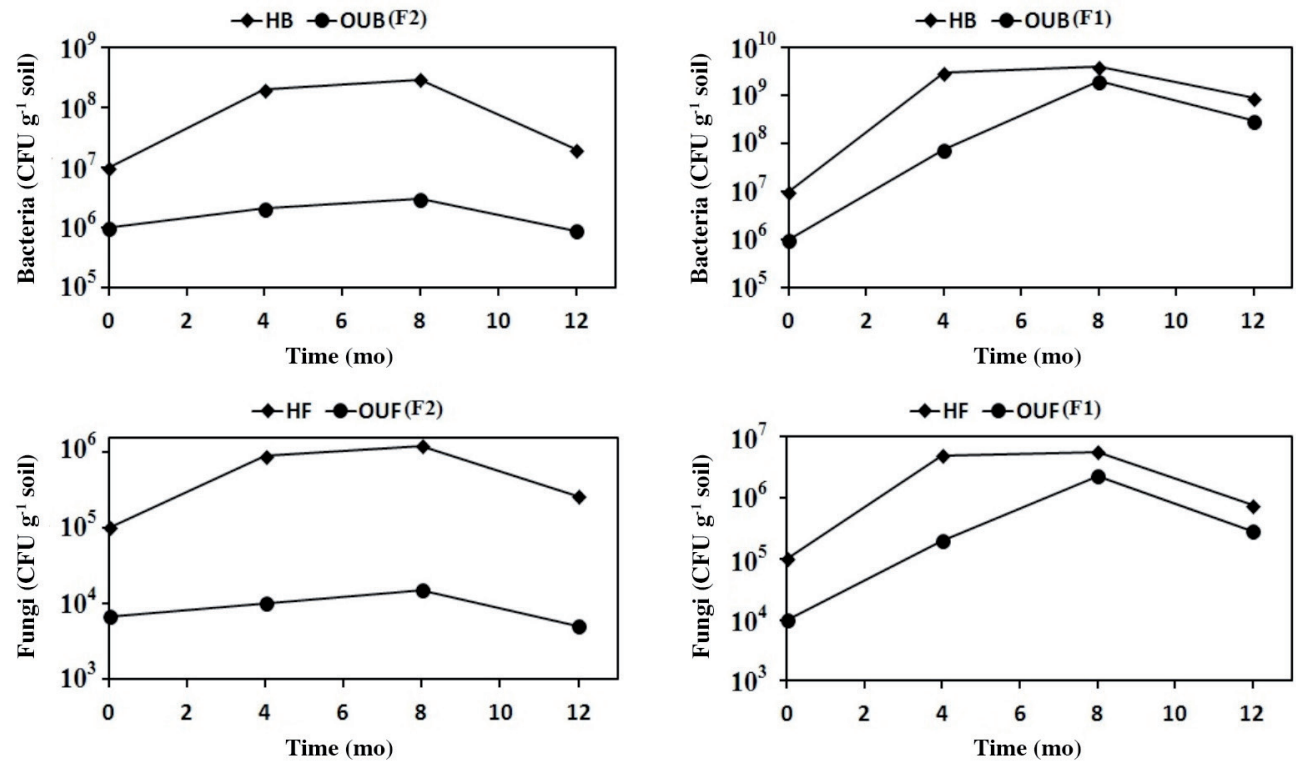

HB: Heterotrophic bacteria; OUB: oil-utilizing bacteria; HF: heterotrophic fungi; OUF: oil-utilizing fungi; $\mathrm{CFU}$ : colony forming units.

Table 5. Bacterial and fungal counts in oil treated field (F1) and untreated field (control) (F2) at 0-75 cm depth.

\begin{tabular}{|c|c|c|c|c|c|c|}
\hline & & $0-15 \mathrm{~cm}$ & $15-30 \mathrm{~cm}$ & $30-45 \mathrm{~cm}$ & $45-60 \mathrm{~cm}$ & $60-75 \mathrm{~cm}$ \\
\hline \multirow{7}{*}{$\mathrm{F} 2$} & & & & $\mathrm{CFU} \mathrm{g}{ }^{-1}$ soi & & \\
\hline & $\mathrm{HB}$ & $2 \times 10^{8}$ & $1.3 \times 10^{8}$ & $0.5 \times 10^{8}$ & $0.1 \times 10^{8}$ & $0.09 \times 10^{8}$ \\
\hline & OUB & $2.1 \times 10^{6}$ & $1.4 \times 10^{6}$ & $0.8 \times 10^{6}$ & $0.1 \times 10^{6}$ & $0.01 \times 10^{6}$ \\
\hline & $(\mathrm{OUB} / \mathrm{HB}) \times 100$ & 0.01 & 0.01 & 0.01 & 0.01 & 0.01 \\
\hline & $\mathrm{HF}$ & $8.8 \times 10^{5}$ & $5.7 \times 10^{5}$ & $2.6 \times 10^{5}$ & $1.8 \times 10^{5}$ & $0.5 \times 10^{5}$ \\
\hline & OUF & $9.9 \times 10^{3}$ & $7.2 \times 10^{3}$ & $4.9 \times 10^{3}$ & $3 \times 10^{3}$ & $0.7 \times 10^{3}$ \\
\hline & $(\mathrm{OUF} / \mathrm{HF}) \times 100$ & 0.01 & 0.01 & 0.01 & 0.01 & 0.01 \\
\hline \multirow[t]{10}{*}{ F1 } & HB & $3 \times 10^{9}$ & $2.2 \times 10^{9}$ & $1.3 \times 10^{9}$ & $0.2 \times 10^{9}$ & $0.07 \times 10^{9}$ \\
\hline & OUB & $7.6 \times 10^{7}$ & $4.7 \times 10^{7}$ & $2 \times 10^{7}$ & $0.1 \times 10^{7}$ & $0.02 \times 10^{7}$ \\
\hline & $(\mathrm{OUB} / \mathrm{HB}) \times 100$ & 2.5 & 0.02 & 0.01 & 0.05 & 0.2 \\
\hline & $\mathrm{HF}$ & $5 \times 10^{6}$ & $4.5 \times 10^{6}$ & $2.1 \times 10^{6}$ & $1.4 \times 10^{6}$ & $0.3 \times 10^{6}$ \\
\hline & OUF & $20 \times 10^{4}$ & $13.2 \times 10^{4}$ & $8.9 \times 10^{4}$ & $5 \times 10^{4}$ & $1.3 \times 10^{4}$ \\
\hline & $(\mathrm{OUF} / \mathrm{HF}) \times 100$ & 0.04 & 0.02 & 0.04 & 0.03 & 0.04 \\
\hline & $(\mathrm{HB}$ in $\mathrm{F} 1 / \mathrm{HB}$ in $\mathrm{F} 2) \times 100$ & 1000 & 1600 & 2600 & 2000 & 700 \\
\hline & $(\mathrm{HF}$ in $\mathrm{F} 1 / \mathrm{HF}$ in $\mathrm{F} 2) \times 100$ & 500 & 700 & 800 & 700 & 600 \\
\hline & $(\mathrm{OUB}$ in $\mathrm{F} 1 / \mathrm{OUB}$ in $\mathrm{F} 2) \times 100$ & 3600 & 3300 & 2500 & 100 & 200 \\
\hline & $(\mathrm{OUF}$ in $\mathrm{F} 1 / \mathrm{OUF}$ in $\mathrm{F} 2) \times 100$ & 2000 & 1800 & 1800 & 1600 & 1800 \\
\hline
\end{tabular}

CFU: Colony forming units; HB: heterotrophic bacteria; OUB: oil-utilizing bacteria; HF: heterotrophic fungi; OUF: oil-utilizing fungi.

It had been shown that bacteria were more active than fungi in the HC biodegradation (Ikuesan, 2017). Such conclusion had also been found by the present study. The mean of HC biodegradation percentage by OUB was $42 \%$ and $20 \%$ by OUF. However, Omotayo et al. (2012) found that the fungi were more active than bacteria in the HC biodegradation. Most biodegradation studies have shown that the potential for microbial biodegradation isolated from oil-contaminated sites was higher than those obtained from non-contaminated sites (Olajire and Essien, 2014). The same finding was arrived in this study. This suggested that crude oil contamination of soil caused adaptation to microbial population for HC biodegradation (Atlas and Hazen, 2011). 
The most active isolated strains in the HC degradation were Arthrobacter polychromogenes, Bacillus cereus, Bacillus polymyxa, Bacillus subtilis, Corynebacterium sp., Flavobacterium indologenes, Micrococcus sp., Pseudomonas fluorescens (bacteria), Penicillium chrysogenum, Fusarium solani, and Aspergillus restrictus (fungi).

The GC analysis revealed that the alkenes were generally the most biodegraded compounds. The pri and phy were the most resistant to microbial breakdown as shown by the ratios of C17/pri and C18/phy. The UCM breakdown significantly when the overall rate of biodegradation was increased (Tables 6,7 and 8). The total or partial resistance of microorganisms to biodegrading isoprenoids and cycloalkanes is well known (Gros et al., 2014).

The $\mathrm{n}$ - and branched alkanes were partially degraded by Aspergillus niger, Candida utilis, Penicillium pinophilum, Psilocybe strictipes, Rhizopus stolonifer, and Saccharomyces cerevisiae. Whereas, $\mathrm{n}$-alkanes were completely assimilated by Arthrobacter polychromogenes, Bacillus cereus, Bacillus polymyxa, Bacillus subtilis, Corynebacterium (AZe26), Corynebacterium (AZe54), Corynebacterium (AZe67), Flavobacterium indologenes, and Pseudomonas fluorescens, which also utilized $95 \%$ of branched alkanes. Aromatic HC were particularly less degraded than alkenes. An exception exists for C. utilis, P. pinophilum, Rhizopus oryzae, and S. cerevisiae that have been biodegraded aromatics at the same rate as alkenes.

Polar fraction was difficult to degrade by microorganisms. There was no oil utilizing microbes that can breakdown the polar fraction significantly. This is due to the fact that this fraction consists mainly of complex structure molecules that are resistant to microbial attack (Atlas and Hazen, 2011). These molecules include resins, N, S and oxygen heterocyclic compounds (Minai-Tehrani et al., 2015). However, Jahangeer and Kumar (2013) reported that some of oil utilizers, especially fungi, were well able to degrade the resin molecules. The degradation rates of organic compounds in petroleum mixture vary widely. The n-alkanes biodegradation is more rapid, followed by simple aromatics, whereas cycloalkanes and aromatics degrade more slowly (Das and Chandran, 2011).

Table 6. Oil-utilizing bacteria (OUB), soil depth of isolation of the bacterial strains from oil treated field (F1) and untreated field (control) (F2), and biodegradation of hydrocarbons (HC).

\begin{tabular}{|c|c|c|c|c|c|c|}
\hline OUB, strain code, and GC pattern & Depth (F1) & Depth (F2) & Alkanes & Aromatics & Polar & $\begin{array}{c}\text { Total } \\
\text { HC }\end{array}$ \\
\hline & \multicolumn{2}{|c|}{$\mathrm{cm}$} & \multicolumn{2}{|c|}{$\%$} & 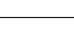 & - \\
\hline Acinetobacter calcoaceticus ${ }^{\mathrm{C}}(\mathrm{AZe} 45)$ & - & $0-15$ & 32 & 6 & -43 & $25 \pm 7$ \\
\hline Acintobacter baumanii ${ }^{\mathrm{C}}$ (AZe73) & - & $30-45$ & 36 & 9 & -26 & $26 \pm 5$ \\
\hline Aeromonas sp. ${ }^{\mathrm{D}}(\mathrm{AZe} 31)$ & $0-15$ & $0-15$ & 51 & 18 & -7 & $41 \pm 13$ \\
\hline Alcaligenes denitrificans ${ }^{\mathrm{D}}(\mathrm{AZe} 44)$ & $15-30$ & - & 52 & 18 & -18 & $44 \pm 6$ \\
\hline Arthrobacter polychromogenes ${ }^{\mathrm{E}}$ (AZe20) & $0-30$ and $60-75$ & - & 80 & 52 & 0 & $66 \pm 8$ \\
\hline Bacillus cereus ${ }^{\mathrm{E}}(\mathrm{AZe} 79)$ & $15-30$ & - & 61 & 28 & -10 & $50 \pm 9$ \\
\hline Bacillus polymyxa $a^{\mathrm{E}}(\mathrm{AZe} 34)$ & $0-30$ & - & 67 & 32 & -37 & $54 \pm 3$ \\
\hline Bacillus pumilus ${ }^{\mathrm{D}}$ (AZe85) & $0-15$ & - & 59 & 25 & -15 & $48 \pm 9$ \\
\hline Bacillus subtilis $^{\mathrm{E}}$ (AZe58) & $0-15$ and $30-45$ & $0-30$ & 75 & 42 & -38 & $59 \pm 5$ \\
\hline Corynebacterium $^{\mathrm{E}}(\mathrm{AZe} 26)$ & $0-15$ & $0-30$ & 63 & 25 & -33 & $52 \pm 5$ \\
\hline Corynebacterium $^{\mathrm{E}}(\mathrm{AZe} 54)$ & $45-60$ & $60-75$ & 77 & 46 & -16 & $61 \pm 6$ \\
\hline Corynebacterium $^{\mathrm{E}}(\mathrm{AZe} 67)$ & $0-45$ & - & 74 & 38 & -53 & $58 \pm 8$ \\
\hline Flavobacterium indologenes ${ }^{\mathrm{E}}(\mathrm{AZe} 66)$ & $0-30$ & - & 62 & 27 & -9 & $52 \pm 9$ \\
\hline Micrococcus sp.. (AZe55) & $0-15$ & - & 67 & 34 & -4 & $53 \pm 1$ \\
\hline Moraxella sp. ${ }^{\mathrm{D}}(\mathrm{AZe} 94)$ & - & $0-15$ & 42 & 13 & -26 & $35 \pm 8$ \\
\hline Mycobacterium sp. ${ }^{\mathrm{D}}$ (AZe72) & $0-15$ & - & 47 & 15 & -35 & $38 \pm 7$ \\
\hline Nocardia sp. $^{\mathrm{C}}(\mathrm{AZe} 87)$ & - & $0-30$ & 38 & 11 & -47 & $37 \pm 11$ \\
\hline Pseudomonas cepacia ${ }^{\mathrm{D}}$ (AZe32) & $0-30$ & $15-30$ and $45-60$ & 57 & 22 & 0 & $46 \pm 1$ \\
\hline Pseudomonas fluorescens ${ }^{\mathrm{C}}$ (AZe95) & $0-30$ & $30-45$ & 63 & 30 & -22 & $53 \pm 8$ \\
\hline Pseudomonas putida ${ }^{\mathrm{D}}$ (AZe19) & $0-15,30-45$ and $60-75$ & $30-45$ & 50 & 16 & 0 & $43 \pm 6$ \\
\hline Pseudomonas pumilus ${ }^{\mathrm{C}}$ (AZe84) & - & $15-30$ & 37 & 10 & -30 & $29 \pm 4$ \\
\hline Pseudomonas vesicularis ${ }^{\mathrm{C}}$ (AZe2) & - & $60-75$ & 33 & 9 & -44 & $24 \pm 7$ \\
\hline Rhodococcus sp. ${ }^{\mathrm{C}}(\mathrm{AZe} 46)$ & - & $15-30$ & 32 & 7 & -19 & $25 \pm 4$ \\
\hline Staphylococcus auriculans ${ }^{\mathrm{D}}$ (AZe63) & - & $0-30$ & 40 & 11 & -53 & $32 \pm 8$ \\
\hline Vibrio sp..$^{\mathrm{C}}(\mathrm{AZe} 28)$ & - & $0-15$ & 31 & 5 & -42 & $22 \pm 9$ \\
\hline Xantomonas sp. ${ }^{\mathrm{D}}$ (AZe62) & $15-30$ & - & 45 & 14 & -36 & $34 \pm 10$ \\
\hline
\end{tabular}

GC: Gas chromatographic.

A-EPatterns of gas chromatographic analysis of hydrocarbons after $30 \mathrm{~d}$ of biodegradation (see Table 8). 
Table 7. Oil-utilizing fungi (OUF), soil depth of isolation of the fungal strains from oil treated field (F1) and untreated field (control) (F2), and biodegradation of hydrocarbons (HC).

\begin{tabular}{|c|c|c|c|c|c|c|}
\hline OUF and GC pattern & Depth (F1) & Depth (F2) & Alkanes & Aromatics & Polar & $\begin{array}{c}\text { Total } \\
\text { HC }\end{array}$ \\
\hline & - & $\mathrm{cm} \longrightarrow$ & & $\%$ & & - \\
\hline Acremonium fusidioides ${ }^{\mathrm{C}}$ (Nicot) W. Gams & $0-15$ & - & 39 & 29 & -5 & $28 \pm 4$ \\
\hline Acremonium kiliense ${ }^{\mathrm{D}}$ Crutz & $15-45$ & - & 40 & 31 & -12 & $26 \pm 8$ \\
\hline Acremonium strictum $^{\mathrm{D}}$ W. Gams & $0-15$ & - & 45 & 33 & -22 & $30 \pm 4$ \\
\hline Aspergillus ustus ${ }^{\mathrm{C}}$ (Bain) Thom and Church & - & $0-15$ & 23 & 16 & -10 & $13 \pm 5$ \\
\hline Aspergillus restrictus ${ }^{\mathrm{D}}$ G. Smith & $0-15$ & - & 47 & 32 & -22 & $40 \pm 6$ \\
\hline Aspergillus terreus ${ }^{\mathrm{C}}$ Thom & - & $0-15$ & 20 & 11 & -5 & $10 \pm 4$ \\
\hline Aspergillus niger ${ }^{\mathrm{B}}$ Van Tieghem & - & $15-30$ and $60-75$ & 11 & 5 & -13 & $8 \pm 10$ \\
\hline Candida utilis $^{\mathrm{A}}$ Minter & - & $0-15$ & 8 & 10 & -10 & $7 \pm 11$ \\
\hline Cladosporium herbarum ${ }^{\mathrm{C}}$ (Persoon:Fries) Link & $45-75$ & $0-15$ & 30 & 22 & -22 & $22 \pm 3$ \\
\hline Cunninghamella echinulata ${ }^{\mathrm{C}}$ (Thaxt.) Thaxt. ex Blakeslee & $0-30$ & $0-15$ & 32 & 26 & -2 & $21 \pm 4$ \\
\hline Cunninghamella elegans ${ }^{\mathrm{C}}$ Lendner & $15-30$ & - & 37 & 21 & -15 & $31 \pm 5$ \\
\hline Fusarium solani $^{\mathrm{D}}$ (Martius) Saccardo & $0-15$ & - & 43 & 30 & -14 & $41 \pm 7$ \\
\hline Microascus cinereus $^{\mathrm{C}}$ (Emile-Weil and Gaudin) Curzi & - & $0-15$ & 20 & 12 & -6 & $9 \pm 13$ \\
\hline Penicillium chrysogenum ${ }^{\mathrm{D}}$ Thom & $0-15$ & - & 54 & 32 & -28 & $46 \pm 9$ \\
\hline Penicillium pinophilum ${ }^{\mathrm{B}}$ Gilman and Abbott & - & $0-15$ and $45-60$ & 10 & 11 & -13 & $5 \pm 11$ \\
\hline Psilocybe strictipes ${ }^{\mathrm{B}}$ Singer and A.H. Smith & $0-30$ & - & 16 & 10 & -11 & $6 \pm 12$ \\
\hline Rhizopus oryzae ${ }^{\mathrm{C}}$ Went and Prins. Geerl. & $15-30$ & - & 21 & 22 & -20 & $11 \pm 3$ \\
\hline Rhizopus stolonifer ${ }^{\mathrm{A}}$ Vuillemin & - & $60-75$ & 7 & 8 & -15 & $4 \pm 10$ \\
\hline Sordaria fimicola ${ }^{\mathrm{C}}$ (Roberge ex Desm.) Ces. and De Not. & $15-30$ & $0-15$ & 39 & 27 & -30 & $27 \pm 2$ \\
\hline Saccharomyces cerevisiae ${ }^{\mathrm{A}}$ Meyen ex E.C. Hansen & - & $0-45$ & 9 & 9 & -10 & $4 \pm 12$ \\
\hline Talaromyces flavus ${ }^{\mathrm{C}}$ (Klocker) Stolk and Smson & $0-15$ & - & 38 & 25 & -24 & $22 \pm 5$ \\
\hline Trichoderma harzianum ${ }^{\mathrm{C}}$ Rifai & - & $0-15$ & 25 & 14 & -22 & $15 \pm 6$ \\
\hline Trichoderma koningii ${ }^{\mathrm{C}}$ Oudemans & $15-45$ & - & 37 & 24 & -11 & $23 \pm 7$ \\
\hline Trichoderma pseudokoningii ${ }^{\mathrm{C}}$ Oudemans & $0-15$ and $30-45$ & $15-30$ & 36 & 18 & -11 & $20 \pm 4$ \\
\hline Trichoderma viride ${ }^{\mathrm{C}}$ Pers. & $30-45$ & $15-60$ & 34 & 20 & -23 & $28 \pm 5$ \\
\hline
\end{tabular}

GC: Gas chromatographic.

${ }^{\text {A-E}}$ Patterns of gas chromatographic analysis of hydrocarbons after $30 \mathrm{~d}$ of biodegradation (see Table 8).

Table 8. Gas chromatographic (GC) patterns, hydrocarbons (HC) biodegradation and HC ratios indicating crude oil biodegradation.

\begin{tabular}{lccccc}
\hline & $\begin{array}{c}\mathrm{GC} \\
\text { pattern A }\end{array}$ & $\begin{array}{c}\mathrm{GC} \\
\text { pattern B }\end{array}$ & $\begin{array}{c}\mathrm{GC} \\
\text { pattern C }\end{array}$ & $\begin{array}{c}\mathrm{GC} \\
\text { pattern D }\end{array}$ & $\begin{array}{c}\mathrm{GC} \\
\text { pattern E }\end{array}$ \\
\hline \% Biodegradation (\% B) & 1 to 9 & 10 to 19 & 20 to 39 & 40 to 59 & 60 to 80 \\
\% B of n-alkanes & $36 \pm 2.1$ & $85 \pm 5.3$ & 100 & 100 & 100 \\
\% B branched alkanes & $9 \pm 1.1$ & $37 \pm 3.4$ & $56 \pm 6.7$ & $89 \pm 5.5$ & $95 \pm 2.4$ \\
\% B cycloalkanes & $5 \pm 0.7$ & $14 \pm 2.6$ & $35 \pm 7.3$ & $57 \pm 9.4$ & $66 \pm 3.6$ \\
C17/Pri & $1.34 \pm 0.13$ & $0.26 \pm 0.02$ & - & - & - \\
C18/Phy & $1.55 \pm 0.01$ & $0.28 \pm 0.03$ & - & - & - \\
n/iso & $0.90 \pm 0.2$ & $0.32 \pm 0.03$ & - & - & - \\
R/UCM & $0.43 \pm 0.2$ & $0.23 \pm 0.1$ & $0.18 \pm 0.05$ & $0.15 \pm 0.03$ & $0.09 \pm 0.02$
\end{tabular}

Pri: Pristane; Phy: phytane; n/iso: n-alkanes/iso-alkanes; R/UCM: resolved n-alkanes/ unresolved complex mixture.

\section{CONCLUSIONS}

The study has shown that agricultural lands contaminated with low oil concentration can allow the growth of plants with minor adverse effects and does not require fertilization or soil treatment other than those required for traditional farming operations. They ensure hydrocarbons (HC) biodegradation in high efficiency with lesser environmental impact. However, some of $\mathrm{HC}$ remain stationary in the soil as organic matter. The vertical infiltration of $\mathrm{HC}$ in the soil plays an important role in removing of these contaminants. When petroleum $\mathrm{HC}$ contaminate soil, they stimulate the oil degrading microorganisms activity. The microbial degraders from oil-contaminated soil utilize the HC more than those from noncontaminated soil. The microbial degraders are found in the entire 0 to $75 \mathrm{~cm}$ soil depth as a result of soil ventilation. The 
bacteria were more efficient in $\mathrm{HC}$ degradation than fungi. Alkanes were the most degraded HC. Isoprenoids, cycloalkanes and aromatics were less degraded. Polar compounds were resistant to microbial attack. Biogenic HC were not broken by microbes. The release of HC metabolic compounds by degraders was demonstrated. Attention should be given to environmentally stable carcinogenic polycyclic aromatic $\mathrm{HC}$.

\section{ACKNOWLEDGEMENTS}

The author would like to thank the College of Science, University of Bagdad, for providing the laboratory facilities.

\section{REFERENCES}

Abatenh, E., Gizaw, B., Tsegaye, Z., and Wassie, M. 2017. The role of microorganisms in bioremediation- A review. Open Journal of Environmental Biology 2:038-046. doi:10.17352/ojeb.000007.

Adams, G.O., Fufeyin, P.T., Okoro, S.E., and Ehinomen, I. 2015. Bioremediation, biostimulation and bioaugmention: A review. International Journal of Environmental Bioremediation \& Biodegradation 3:28-39. doi:10.12691/ijebb-3-1-5.

Atlas, R.M., and Hazen, T.C. 2011. Oil biodegradation and bioremediation: A tale of the two worst spills in U.S. history. Environmental Science Technology 45:6709-6715. doi:org/10.1021/es2013227.

Chorom, M., Shariffi, H.S., and Mutamedi, H. 2010. Bioremediation of a crude-oil polluted soil by application of fertilizers. Iran Journal of Health Science Engineering 7:319-326.

Chukwura, E.I., Ojiegbu, M.N., and Nwankwegu, A.S. 2016. Hydrocarbon degradation potentials of fungi associated with oil-contaminated soil from selected mechanic workshops in Awka, Anambra State, Nigeria. Frontiers in Environmental Microbiology 2:38-44. doi:10.11648/j.fem.20160206.13.

Dadrasnia, A., and Agamuthu, P. 2013. Dynamics of diesel fuel degradation in contaminated soil using organic wastes. International Journal of Environmental Science and Technology 10:769-778. doi:10.1007/s13762-013-0224-1.

Das, N., and Chandran, P. 2011. Microbial degradation of petroleum hydrocarbon contaminants: An overview. Biotechnology Research International 2011:1-13. doi:10.4061/2011/941810.

Essaid, H., Bekins, B.A., Herkelrath, W.N., and Delin, G.N. 2011. Crude oil at the Bemidji site: 25 years of monitoring, modeling, and understanding. Ground Water 49:706-726. doi:10.1111/j.1745-6584.2009.00654.x.

Eze, V.C., Onwuakor, C.E., and Orok, F.E. 2014. Microbiological and physicochemical characteristics of soil contaminated with used petroleum products in Umuahia, Abia State, Nigeria. Journal of Applied and Environmental Microbiology 2:281-286. doi:10.12691/jaem-2-6-3.

Fowzia, A., and Fakhruddin, A.N.M. 2018. A review on environmental contamination of petroleum hydrocarbons and its biodegradation. International Journal of Environmental Sciences and Natural Resources 11(3):555811. doi:10.19080/IJESNR.2018.11.555811.

Gadd, G.M., Watkinson, S.C., and Dyer, P.S. 2007. Fungi in the environment. 406 p. Cambridge University Press, London, UK.

Gawdzik, J., and Zygadlo, M. 2010. Modelling transport of hydrocarbons in soil-water environment. Ecological Chemistry and Engineering 17:331-343.

Gros, J., Reddy, C.M., Aeppli, C., Nelson, R.K., Carmichael, C.A., and Arey, J.S. 2014. Resolving biodegradation patterns of persistent saturated hydrocarbons in weathered oil samples from the deepwater horizon disaster. Environmental Science Technology 48:1628-1637. doi:10.1021/es4042836.

Guo, P., He, S., Zhu, S., Chai, D., Yin, S., Dai, W., et al. 2014. Formation and identification of unresolved complex mixtures in lacustrine biodegraded oil from Anxiang basin, China. The Scientific World Journal 2014:1-10. doi:org/10.1155/2014/102576doi.

Hajabbasi, M.A. 2016. Importance of soil physical characteristics for petroleum hydrocarbons phytoremediation: A review. African Journal of Environmental Science and Technology 10:394-405. doi:10.5897/AJEST2016.2169.

Han, G., Cui, B.X., Zhang, X.X., and Li, K.R. 2016. The effects of petroleum-contaminated soil on photosynthesis of Amorpha fruticosa seedlings. International Journal of Environmental Science and Technology 13:2383-2392. doi:10.1007/s13762-016-1071-7.

Holt, J.G., Krieg, N.R., Sneath, P.H.A., Staley, J., and Williams, S.T. 1994. Bergey's manual of determinative bacteriology. $9^{\text {th }}$ ed. 753 p. Williams and Wilkins Publishers, Baltimore, Maryland, USA.

Ikuesan, F.A. 2017. Evaluation of crude oil biodegradation potentials of some indigenous soil microorganisms. Journal of Scientific Research and Reports 13:1-9. doi:10.9734/JSRR/2017/29151.

Jahangeer, and Kumar, V. 2013. An overview on microbial degradation of petroleum hydrocarbon contaminants. International Journal of Engineering and Technical Research 1:34-37.

Jain, P.K., Gupta, V.K., Gaur, R.K., Lowry, M., Jaroli, D.P., and Chauhan, U.K. 2011. Bioremediation of petroleum oil contaminated soil and water. Research Journal of Environmental Toxicology 5:1-26. doi:100.3923/rjet.2011.1.26. 
Li, Q., Lu, Y., Shi, Y., Wang, T., Ni, K., Xu, L., et al. 2013. Combined effects of cadmium and fluoranthene on germination, growth and photosynthesis of soybean seedlings. Journal of Environmental Sciences 25:19361946. doi:10.1016/S1001-0742(12)60264-2.

Makadia, T.H., Adetutu, E.M., Simons, K.L., Jardine, D., Sheppard, P.J., and Ball, A.S. 2011. Re-use of remediated soils for the bioremediation of waste oil sludge. Journal of Environmental Management 92:866-871. doi:10.1016/j.jenvman.2010.10.059.

Minai-Tehrani, D., Rohanifar, P., and Azami, S. 2015. Assessment of bioremediation of aliphatic, aromatic, resin, and asphaltene fractions of oil-sludge-contaminated soil. International Journal of Environmental Science 12:1253-1260. doi:10.1007/s13762-014-0720-y.

Olajire, A.A., and Essien, J.P. 2014. Aerobic degradation of petroleum components by microbial consortia. Journal of Petroleum and Environmental Biotechnology 5:195. doi:10.4172/2157-7463.1000195.

Omotayo,A.E., Ojo, O.Y., and Amund, O.O. 2012. Crude oil degradation by microorganisms in soil composts. Research Journal of Microbiology 7:209-218. doi:10.3923/jm.2012.209.218. 